\title{
THE REVEALING CASE OF CULTURAL CREATIVES AS TRANSMODERN TOURISTS IN SOWETO, SOUTH AFRICA
}

\author{
Sandile L. MKHIZE * \\ University of Johannesburg, School of Tourism and Hospitality, \\ College of Business and Economics, South Africa, e-mail: sandile.lmkhize@gmail.com \\ Milena IVANOVIC \\ University of Johannesburg, School of Tourism and Hospitality, \\ College of Business and Economics, South Africa, e-mail: mivanovic@uj.ac.za
}

\begin{abstract}
Citation: Mkhize S.L., \& Ivanovic M., (2019). THE REVEALING CASE OF CULTURAL CREATIVES AS TRANSMODERN TOURISTS IN SOWETO, SOUTH AFRICA. GeoJournal of Tourism and Geosites, 26(3), 993-1005. https://doi.org/10.30892/gtg.26324-412
\end{abstract}

\begin{abstract}
This article investigates the phenomenon of transmodern tourism in Soweto as it statistically tests the theoretical assumption that Cultural Creatives are a clearly identifiable group of transmodern tourist in general tourists population. The results of ANOVA confirmed a group difference between Cultural Creatives and general tourists, leading to a major finding that Cultural Creatives presence in Soweto (54.8\%) is two-times (26.1\%) more than the value predicted by the literature. In addition, Walking around the township is identified as Cultural Creatives' most authentic experience which further validates the recommendation for development of an innovative range of immersive and authentic experiences in Soweto that conforms to Cultural Creative's transmodern value system.
\end{abstract}

Keywords: Transmodernism, Cultural Creatives, Authenticity, Transformative experience, Conscious consumers, Soweto

\section{INTRODUCTION}

The world out there is changing at an unprecedented rate. These changes are not only environmental, economic, social and political but mounting evidence point to a rise of a new planetary consciousness and new world order known as transmodernism (Ateljevic, 2009, 2011; Ghisi, 1999, 2008:158, 2010; Pritchard et al., 2011:941; Rifkin, 2005; Rodriguez, 1989, 2017). Transmodernism is evident in all aspects of people's lives, from consumption, value(s) system, work, leisure patterns, global ecological awareness, to concerns for the survival of the humankind and the quest for more fulfilling and spiritual lives. In the forefront of transmodernism is a silent but powerful class of transmodern consumers known as Cultural Creatives (Ray, 2008; Ray \& Anderson, 2000). They are converging across the nations creating a new, wiser, transmodern culture embedded in a

\footnotetext{
${ }^{*}$ Corresponding author
} 
post-capitalist, post-modernist holistic value system way beyond postmodernity (Rifkin, 2005:121). Even though Cultural Creatives are still lacking a sense of self-identity or group identity as was historically the case with other subcultures (Hippies, New agers, Baby boomers etc) they can be identified based on their transmodern worldviews and their new value system. They are conscious consumers who reject the postmodern obsession with consumerism and materialism and stand for a new, just and sustainable world. The mounting evidence exist that Cultural Creatives are in fact leading a silent revolution towards a new global value system and a new transmodern world order on a scale not experienced in the past 600 years, since the Renaissance (Ateljevic, 2009; Gelter, 2010; Ghisi, 2010; Pritchard et al., 2011; Rodriguez, 1989, 2004; Tribe, 2008, 2009). The emergence of the Cultural Creatives has profound implications for tourism because they uphold the same life values in everyday life as they do in travel (Ray \& Anderson, 2000). They demand travel to be an educational, experiential, authentic, altruistic and/or spiritual experience leading to personal transformation through learning and discovery (Ivanovic, 2014; Tomljenovic, 2015). Their interaction in a destination is sustainable and honest as they immerse themselves in the local culture, while showing respect for local people and their way of life. In the same vein, Cultural Creatives are genuinely interested in the problems of the destination for which they seek long-term environmental and socio-economic solutions as they tend to come back as volunteers or make a difference in the ways that matter (Reisinger, 2015; Wolf et al., 2017).

It is with the prevalence of Cultural Creatives as a new breed of conscious consumers/tourists that the need for the creation of new authentic experiences arises and, consequently, the need for an economic alignment of products use-value with the consumers authentic self-image (Ivanovic \& Saayman, 2015:33).

There is no doubt that authentic experiences that fit into the new transmodern value system of Cultural Creatives as tourists will be paving the way for the organic development of transmodern tourism in the world and subsequently in Africa and South Africa. Contrary to expectations, an extensive literature review revealed that there are only a few research studies focusing on either transmodernism or prevalence of Cultural Creatives and their experiences in the major world tourism destinations and there was not one African or South African study with the same focus. A complete lack of understanding who these new transmodern tourists visiting South Africa are, and what kind of experiences and activities they want is not helping the South African tourism agenda focusing on job creation and poverty alleviation (Strydom et al., 2019:8). In order to address the shortcomings identified in the literature and provide some basic understanding of the way transmodernism is shaping the new tourists experience in South Africa, the aim of this article is to apply a transmodern value system as identified by Ray and Anderson (2000) in detecting Cultural Creatives among international tourists visiting Soweto. The article statistically tests the theoretical assumption that due to a profound transmodern value system that they uphold, the Cultural Creatives are a clearly identifiable group of transmodern tourists. This assumption is strengthened by Ray's (2008:6) clarification that, as part of the subculture, Cultural Creatives come "with new values, lifestyle and worldviews, and these cannot be predicted by demographics because they are deeper than demographics". In the same vein the article is set to uncover what activities and experiences are undertaken by Cultural Creatives in Soweto which contribute the most to their authentic experience while conforming to tourist transmodern value system and lifestyle anticipated by the literature.

\section{THEORETICAL FRAMEWORK}

The theoretical framework pertinent to this article presents an overview of transmodernism as the new world order and a dominant paradigm: Cultural Creatives as 
a powerful group of consciousness consumers at the forefront of transmodernism; and transformatory experience as a type of new immersive authentic experience in tourism.

\section{Transmodernity}

Three prominent philosophers, Spanish Rodriguez Magda (1989, 2017), Belgian Luychx Ghisi (1999, 2008, 2010), and Argentinian-Mexican Enrique Dussel (2002) laid the foundation for the concept of transmodernity. Defined as an all-encompassing "socio-cultural, economic, political and philosophical shift" way beyond postmodernism, transmodernism carries a universal message of hope for the survival of humankind (Ateljevic, 2009). As a post-industrial contemporary concept, transmodernity represents a decline in the dominant Euro-American industrial, patriarchal, imperial, capitalistic and colonial world-system of the modern society, thus embodying the African decolonising paradigm (Dussel, 2002; Ghisi, 2008). In the heart of transmodernism is Dussel's (2002) Philosophy of Liberation, a global project which rejects the European superiority of the last five centuries and unmasks the invention of the Other, of the colonized Africans in particular (Mekonnen, 2012:10). As such, it is undoubtedly an emerging xenophilian consciousness, a celebration of local and global diversity based on greater tolerance for ethnic, racial and sexual differences (Gelter, 2010).

Transmodernity is also a paradigmatic societal transformation that transcends the two earlier paradigms and world orders: modernism and postmodernism. Modernism is associated with the Fordist economy of scales driven by mass production of products and services with universal appeal. It is founded on Western assumption of rational inquiry and scientifically proven truths which in turn negate intellectual diversity and tolerance leading to unfairness and oppression for others. Modernism as a societal system is noninclusive as it advocates each individual to pursue success, which, in the western vernacular, has generally meant the rat race for financial success and status display leading to alienation (Ray, 2008: 12; Rifkin, 2005). For this reason, the alienated modern man as a tourist is in constant search of authenticity in other places and other times, the search damned to inauthenticity because they cannot escape the mass produced and irrevocably commodified tourism spaces. Postmodernism is seen as the antithesis to modernism as it is associated with the Post-Fordist economy of scope changing the economic focus from mass production to mass consumption (Pine \& Gilmore, 2012). As a worldview postmodernism represents a deconstruction of reality whereby everyone's narrative is equally compelling. This in turn leads to endless differentiations of reality resulting in cultural diversity, competing beliefs, pluralism, ambiguity and the stagnation of the modern value of progression, culminating with 'meaningless hyper-consumerism' of the postmodern society (Ateljevic, 2009; Ateljevic \& Tomljenovic, 2016:28; Rikfin, 2005; Tribe, 2009). As the reality retreats it leads to a complete collapse of real and hyper-real into one reality, a simulacrum as a spectacle, an experiential form in which the real, authentic objects and events are replaced by simulated artificial, hyper-real fantasy world. In tourism, it leads to a dominance of a simulated reality (Disney World alike) in which post-tourists replace authenticity with an inauthentic experience of reality lacking depth and superficiality in understanding other cultures.

As both paradigms have reached a point where they can no longer proceed on their own as dominant worldviews, transmodernism, as a synthesising paradigm, is capable of taking the two preceding paradigms, modernism and postmodernism, from the edge of chaos towards an all-inclusive and democratic order of society. In the forefront of transmodernism is the new trans-capitalist economic order known as the authentic economy (Gilmore \& Pine, 2007). In authentic economy, all consumers request authenticity as the new purchasing criteria. In every sector of economy businesses must add authenticity of experience as a value to be managed as a critical component of 
production and consumption. Even more importantly, what consumers purchase (tourists included) should conform to their own self-image as an authentic-self and what they buy must reflect who they are and who they aspire to be in relation to how they perceive the world. The offerings that do not appeal to the authentic self-image are regarded inauthentic or fake as is the case of Cultural Creatives, discussed below.

\section{Cultural Creatives}

In 2000, Dr Paul Ray and Sherry Ruth Anderson discovered a silent group of consumers, calling them the Cultural Creatives, as a surprising result of the longitudinal psychographic research on over 100,000 Americans and 100 focus groups on consumer values and beliefs. The results were published in the book 'Cultural Creatives: How 50 Million people are changing the world' suggesting that $24 \%$ or about 50 million adults at that time (hence the book title) of the US adult population fall into the new Cultural Creatives subculture. Subsequent research by Ray (2008) suggest that Cultural Creatives account for $26.1 \%$ of the world's population revealing their annual rise of $3 \%$ since they were first detected in 2000. As clearly identifiable sub-culture, Cultural Creatives dedicate their lives to the pursuits of personal development and growth, a purposeful life grounded in spirituality while at the same time making a positive change on the planet (Ray \& Anderson, 2000; Florida, 2012). Cultural Creatives are competent, inner-directed activists with convictions that are so strong that they can steer their values, lifestyle and subculture undeterred in spite of opposing value pressures from the larger culture in which they live (Ray \& Anderson, 2000; Ray, 2008). They demand authenticity in every sphere of their lives, "at home, in stores, at work, in politics" and in travel (Ray \& Anderson, 2000:5). In their lifestyle choices, they strive to balance rationality (facts) and intuition (feelings) for the best of both worlds. The surfacing of the Cultural Creatives as a socio-political movement or sacred activism, stems from the realisation that human capabilities come from within and, therefore, reaffirm individual growth, spirituality and actions that counter contemporary global discourses of fear, alienation and disempowerment (Ateljevic, 2009: 290).

\section{Transformatory tourist experience}

Following a shift in the tourist experience from staged pseudo-events to rendering authenticity, the quest for authentic experiences in tourism has become paramount (Pine \& Gilmore, 2012; Morrison et al., 2017). With its alignment to transmodernism, new tourism trends have the unrestricted potential to initiate personal and societal transformation towards newly emerging life values and world-views evident in a silent subculture of Cultural Creatives (Robledo \& Batle, 2017; Reisinger, 2015; Tomljenovic, 2015:4; Wolf et al., 2017). A change in life values towards self-discovery, independence, care for places visited and a quest for deeper meaning and self-development is the basis of human progression which makes people mentally free when travelling and thus motivating them to develop, unfold and actualize their inner human potential (Welzel, 2006). In essence, tourism experiences that are somewhat challenging but aligned to individual's values and conform to an individual experience of the real world and an authentic-self, are defined as transformational (Tomljenovic, 2015: 5).

As such, transformation is the highest order need, positioned beyond selfactualisation on the Maslow's pyramid of needs (Gelter, 2010:48). When individuals feel themselves to be both in touch with the real world and with their real selves, they are having an authentic experience. Since transformational experience is founded in tourists demand for an authentic experience in all spheres of their lives, such demand should be managed as a critical component of production and consumption of experiences in tourism (Gilmore \& Pine, 2007). Contrary to Cultural Creatives who, as tourists, demand authenticity and personal transformation through immersive tourist experiences, the post-tourists are in search of simulacra as an illusion of authenticity, rather than a 
definitive reality. As post-tourist do not share the same world values and do not demand deep authentic experience as Cultural Creatives do, the two groups can be clearly delineated. Since a core business of tourism as part of new authentic economy is to sell experiences, the issue of authenticity in tourism in its transmodern form is expected to change its experience game in the very near future (Ivanovic \& Saayman, 2015:25).

\section{MATERIALS AND METHODS}

This is an exploratory mixed method study based on a survey $(\mathrm{N}=252)$ derived from Anderson and Ray (2000) questionnaire consisting of 16 transmodern life values. Qualitative methods included semi-structured interviews $(\mathrm{n}=20)$ as means of ensuring validity of the survey findings, and non-participant observations (diary and photos) as a method of monitoring the behaviour of tourists during their visit (are they walking around Soweto on their own, are they breaking away from the group, do they behave ethically towards locals eg. not taking photos without permission etc.). Non-probability quota sampling is selected as the main method of data collection in order to ensure representativity of the samples in exact proportion to their respective quantities in official national statistics (Americas, Europe, Asia \& Australasia, and the Middle East).

This was done in order to infer the result and compare the actual percentage of Cultural Creatives in Soweto with the expected presence of Cultural Creatives in the general population world-wide. As already pointed out, there is not yet a world map of the spread of Cultural Creatives globally and there is not yet data available that accounts for the number of Cultural Creatives in South Africa. However, for the purpose of this study, two estimates are used as the baseline; Ray's (2008) estimate of $26.1 \%$ share of Cultural Creatives in the global population, and Ivanovic and Saayman (2015) estimate that 18.3\% of purposeful cultural tourists visiting South Africa can be regarded the closest representatives of Cultural Creatives. Therefore, the assumption is that a minimum of one out of every five (1:5) international (long haul) tourists coming into Soweto should be the closest representation of a Cultural Creative. The proportional quota sample retrieved for this study $(\mathrm{N}=252)$ of inbound international tourists visiting South Africa from respective generating regions (Table 1) is deemed reliable (at 95\% confidence level) as it mirrors the same inbound tourist stratums as per the official national statistic (StatsSA, 2018).

As a second layer of sampling, purposeful sampling based on tourists behaviour was simultaneously employed to ensure Cultural Creatives are included since they cannot be identified based on profiles or demographics. While maintaining strata mirroring for tourist generating regions the respondents are further selected based on the following criteria: (1) tourists from a local backpacker establishment (51), tourists wandering alone in the township (151), and general tourists in coach/planned tours (50). Identifying three groups based on behavioural preferences is done for purely practical reasons to ensure Cultural Creatives are represented in the sample based on their expected preferences while in Soweto. Delineation between three groups was also necessary to facilitate a statistical comparison within and between the groups to clearly identify Cultural Creatives based on their life values. The survey data was captured and coded using Microsoft Excel while the Statistical Package for the Social Sciences (SPSS) version 2.3 was used for data analysis. Data collection took five months to complete, o3 January 2018 - 30 May 2018, carried out by one of the authors who is a Soweto native.

\section{Questionnaire development}

Given the complexity of the terms and tourist's unfamiliarity with underlying values of transmodernism, the questionnaire was pre-tested on two occasions (11th - 12th August 2017 \& 18th - 19th August 2017) and further piloted based on 40 questionnaires (8th September - 21st October 2017). A number of changes were made to the 
questionnaire according to the aspects identified in the pre-tests and pilot questionnaires. Despite changes in the wording of the 28 value statements, the questionnaire was kept in accordance with the most consistent 16 values identified by Ray \& Anderson (2000) and Ray (2008) surveys. The Cronbach's Alpha, $\alpha=0.624$, confirms the internal validity of the 1-4 Lickert scale as the instrument items are reflective of the underlying transmodern constructs. Therefore, as survey respondents agree or disagree to 28 statements in the worldview scale (Table 2) measuring 16 dimensions/values of transmodernity, they can be classified as either a close representative of a Cultural Creative or as the others who are the general tourists. The differentiated spread of Mean value score, including 5 adjusted negative values, $\mathrm{M}=19.05(\mathrm{SD}=3.78, \mathrm{~N}=252)$, was used to identify Cultural Creatives from general tourists. The use of a 4-point forced answer Likert scale not leaving an option for respondents to remain neutral, is justified by the following two reasons (Pallant, 2011). Firstly, transmodern phenomenon deals with a whole set of new world-views and values the meaning of which would be very difficult to interpret in case of neutral responses. Secondly, forcing respondents to decide which transmodern values they uphold allows for more precision during data analysis.

\section{Area of study: Soweto}

Soweto is a significant tourist node in South Africa attracting 212000 tourists in 2016 (SAT, 2017:82). Tourists are interested in seeing the main symbols of South Africa's struggle against the apartheid (Mandela House in Vilakazi Street and the Hector Pieterson Museum), as well as how the country has progressed since its first democratic elections in 1994. Township tours to Soweto, therefore, continue to gain considerable popularity amongst tourists visiting South Africa who want to see the 'real' people of Soweto (Ramchander, 2007). Soweto has become a symbol of oppression and liberation, thus, the freedom values associated with Soweto are in line with what new emerging transmodern consciousness and Cultural Creatives stand for, validating the choice of Soweto as the study area. Figure 1 is a map of Soweto highlighting the areas where the tourists were targeted.

Table 1. Demographic characteristics

\begin{tabular}{|l|l|c|c|}
\hline N=252 & Frequency & \% \\
\hline Age groups & $19 \&$ younger & 34 & 14.5 \\
\hline \multirow{5}{*}{ Gender } & $20-29$ & 121 & 51,3 \\
\cline { 2 - 4 } & $30-39$ & 53 & 22,5 \\
\cline { 2 - 4 } & $40-49$ & 17 & 7,2 \\
\cline { 2 - 4 } & 50 \& above & 11 & 4.7 \\
\hline \multirow{5}{*}{ Highest education } & Male & 113 & 44,8 \\
\hline & Female & 129 & 51,2 \\
\cline { 2 - 4 } & LGBTQ & 10 & 4 \\
\hline & Primary/Secondary & 39 & 15,9 \\
\cline { 2 - 4 } & Vocational & 34 & 13,9 \\
\cline { 2 - 4 } & Bachelor's Degree & 96 & 39,2 \\
\cline { 2 - 4 } & Oasters/Doctoral degree & 63 & 25,7 \\
\cline { 2 - 4 } & Other & 13 & 5,3 \\
\hline \multirow{5}{*}{ Country of origin } & Africa & 56 & 22,4 \\
\hline & Europe & 128 & 51,2 \\
\cline { 2 - 4 } & Middle East & 5 & 2 \\
\cline { 2 - 4 } & Asia \& Australasia & 15 & 6 \\
\cline { 2 - 4 } & Americas & 46 & 18,4 \\
\hline
\end{tabular}

\section{RESULTS DISCUSSIONS}

\section{Demographic characteristics}

Apart from the slight dominance of female visitors, (53.3\%), a significant $73.8 \%$ of the visitors fall into the $20-39$ years age category and a staggering $65 \%$ of respondents 
were highly educated (39.2\% Bachelor's degree and 25.7\% Master's/Doctoral degree). Even though demographic characteristics of Cultural Creatives visiting Soweto are revealing, they are not reflective of Cultural Creatives life values and transmodern worldviews, and cannot be used as a selection criteria in future studies.

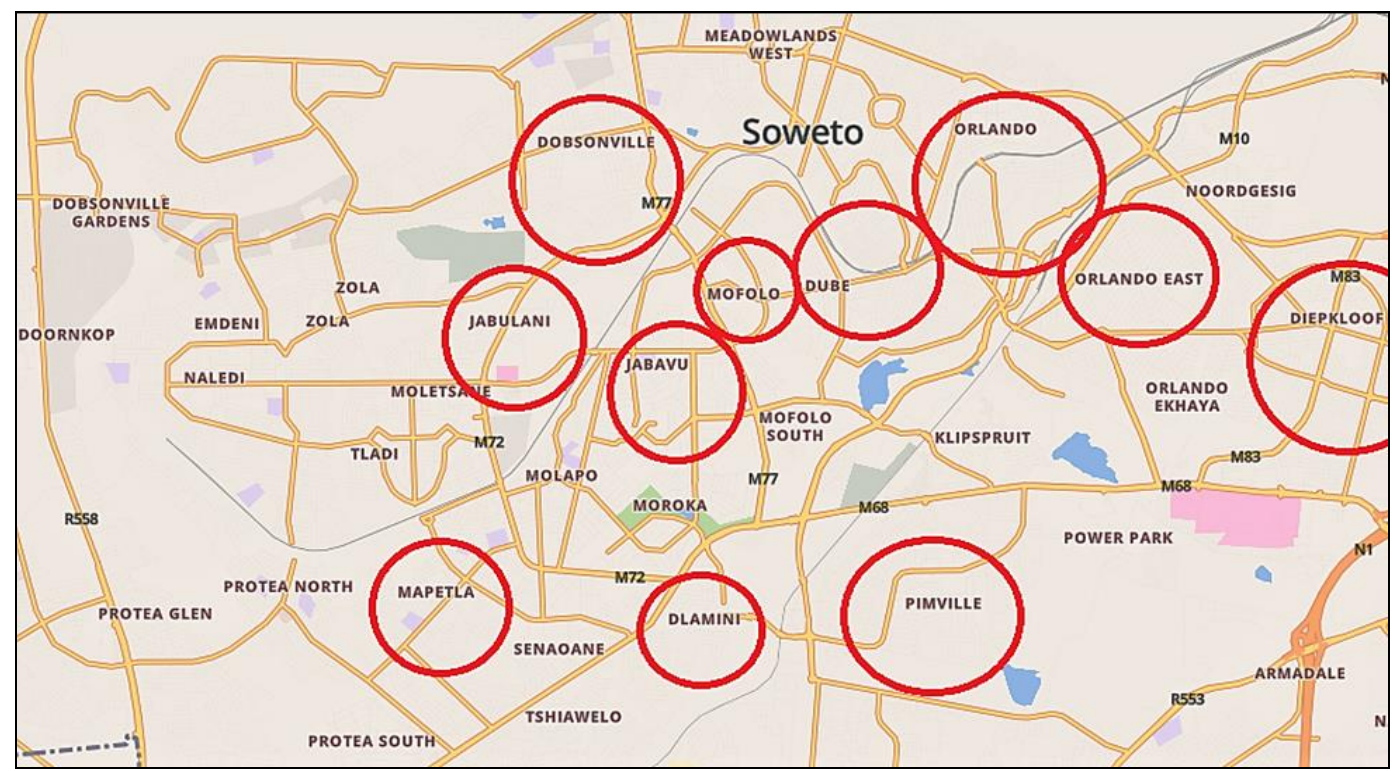

Figure 1. Map of Soweto (Source: AfriGis, 2019)

\section{Transmodern values}

As conscious consumers, the Cultural Creatives are standing for the transmodern values they consider important and are taking active action towards their realisation (recycling, healthy lifestyle/food, minimalism, pro-feminism etc.) (Gelter, 2010; Ghisi, 2008:158). The most important Cultural Creatives' transmodern values identified by Ray (2008) were: (1) to see nature as sacred (89\%), (2) concern about the condition of women and children worldwide and at home (87\%), and (3) liking what is foreign and exotic in other cultures (xenophiles) (85\%). Demand for authenticity (63\%), self-actualization (63\%) and spirituality (46\%) were clearly taking a back seat. The results presented in Table 2 reconfirm the dominance of the top two values identified by Ray, the xenophiles (89.6\%) and pro-feminism (81.25\%). Surprisingly, in only a decade, desire for selfactualisation (78.1\%) and authenticity (70.15\%) emerged as top values, further serving as a proof of an emerging transmodern value system. The fact that the results of this study, presented in Table 2, overlap with those identified by Ray (2008:7), is further confirmation of the validity of the scale and the study's findings.

The results of the value scale further confirm that $54.8 \%$ of tourists visiting Soweto are closest representatives of Cultural Creatives, of whose, as expected, $72.5 \%$ are in backpackers group, $58.3 \%$ are wandering tourists, and $26 \%$ are general tourists.

\section{ANOVA one-way between groups analysis of variance}

In this study, one-way ANOVA is conducted to test if there was a statistically significant difference in the Mean scores of the three dependent groups (backpackers, general tourists and wandering tourists) against the Cultural Creative score as an independent variable (Pallant, 2011:105). The ANOVA results show $(\mathrm{F}=17.65, \mathrm{p}$ $=0.001, \mathrm{p}<0.05$ ) that the Sig. value is less than 0.05 meaning that somewhere between 
and within the three groups there is a statistically significant difference among the Mean scores. However, the ANOVA does not show where the statistically significant difference is. To find this difference, the Dunnett T3 test was used.

Table 2. The results of Transmodern worldviews and life values Likert scale

\begin{tabular}{|c|c|c|c|c|c|}
\hline $\begin{array}{c}\text { Transmodern values \& } \\
\text { worldviews }\end{array}$ & \begin{tabular}{|c|} 
Strongly \\
disagree \% (n)
\end{tabular} & $\begin{array}{l}\text { Disagree } \\
\text { \% (n) }\end{array}$ & $\begin{array}{l}\text { Agree } \\
\text { \% (n) }\end{array}$ & $\begin{array}{c}\text { Strongly } \\
\text { agree \%(n) }\end{array}$ & Mean \\
\hline \multicolumn{6}{|l|}{ (1) Xenophilism } \\
\hline $\begin{array}{l}\text { I easily connect with people from a } \\
\text { different race and culture }\end{array}$ & $\begin{array}{l}1,7 \\
(4)\end{array}$ & $\begin{array}{l}8,8 \\
(21)\end{array}$ & $\begin{array}{l}38,8 \\
(93)\end{array}$ & $\begin{array}{l}50,8 \\
(122)\end{array}$ & $\begin{array}{c}3 \cdot 3 \\
9\end{array}$ \\
\hline \multicolumn{6}{|l|}{ (2) Self-actualization } \\
\hline $\begin{array}{l}\text { Knowledge is for sharing, not for } \\
\text { keeping to oneself }\end{array}$ & $\begin{array}{l}2,9 \\
(7)\end{array}$ & $\begin{array}{l}11,2 \\
(27)\end{array}$ & $\begin{array}{l}24,9 \\
(60)\end{array}$ & $\begin{array}{l}61,0 \\
(147)\end{array}$ & $\begin{array}{c}3.4 \\
4\end{array}$ \\
\hline $\begin{array}{l}\text { This trip has helped me rediscover } \\
\text { myself }\end{array}$ & $\begin{array}{l}5,4 \\
(13)\end{array}$ & $\begin{array}{l}24,4 \\
(59)\end{array}$ & $\begin{array}{c}52,1 \\
(126)\end{array}$ & $\begin{array}{l}18,2 \\
(44)\end{array}$ & $\begin{array}{c}2.8 \\
3\end{array}$ \\
\hline \multicolumn{6}{|l|}{ (3) Desire for authenticity } \\
\hline $\begin{array}{l}\text { I only buy brands which are reflective } \\
\text { of my values }\end{array}$ & $\begin{array}{c}8,2 \\
(20)\end{array}$ & $\begin{array}{l}36,1 \\
(88)\end{array}$ & $\begin{array}{l}39,8 \\
(97)\end{array}$ & $\begin{array}{l}16,0 \\
(39)\end{array}$ & 2.64 \\
\hline Travelling helps me reconfirm my values & $\begin{array}{l}3,7 \\
(9)\end{array}$ & $\begin{array}{l}11,8 \\
(29)\end{array}$ & $\begin{array}{l}48,6 \\
(119)\end{array}$ & $\begin{array}{l}35,9 \\
(88)\end{array}$ & 3.17 \\
\hline \multicolumn{6}{|l|}{ (4) For spirituality } \\
\hline I believe in spiritually, not a religion & $\begin{array}{l}11,9 \\
(29)\end{array}$ & $\begin{array}{l}20,2 \\
(49)\end{array}$ & $\begin{array}{l}40,3 \\
(98)\end{array}$ & $\begin{array}{l}27,6 \\
(67)\end{array}$ & 2.84 \\
\hline $\begin{array}{l}\text { I have experienced being spiritually } \\
\text { absorbed into something greater than } \\
\text { myself }\end{array}$ & $\begin{array}{c}8,5 \\
(210)\end{array}$ & $\begin{array}{l}30,2 \\
(75)\end{array}$ & $\begin{array}{l}44,8 \\
(111)\end{array}$ & $\begin{array}{l}16,5 \\
(41)\end{array}$ & 2.69 \\
\hline \multicolumn{6}{|l|}{ (5) Minimalism } \\
\hline I own things I don't really use & $\begin{array}{c}7,6 \\
(19)\end{array}$ & $\begin{array}{l}28,0 \\
(70)\end{array}$ & $\begin{array}{l}46,0 \\
(115)\end{array}$ & $\begin{array}{l}18,4 \\
(46)\end{array}$ & 2.73 \\
\hline I only buy things that I really need & $\begin{array}{c}8,2 \\
(20)\end{array}$ & $\begin{array}{l}32,8 \\
(80)\end{array}$ & $\begin{array}{l}36,5 \\
(8) 9\end{array}$ & $\begin{array}{l}22,5 \\
(5,5)\end{array}$ & 2.75 \\
\hline \multicolumn{6}{|l|}{ (6) Eco-sustainability } \\
\hline I always recycle wherever I go & $\begin{array}{c}8,9 \\
(22)\end{array}$ & $\begin{array}{l}29,3 \\
(72)\end{array}$ & $\begin{array}{l}42,7 \\
(105)\end{array}$ & $\begin{array}{l}19,1 \\
(47)\end{array}$ & 2.72 \\
\hline $\begin{array}{l}\text { I often support animal protection } \\
\text { initiatives }\end{array}$ & $\begin{array}{l}4,0 \\
(10)\end{array}$ & $\begin{array}{l}36,1 \\
(90)\end{array}$ & $\begin{array}{l}46,2 \\
(115)\end{array}$ & $\begin{array}{l}13,7 \\
(34)\end{array}$ & 2.69 \\
\hline \multicolumn{6}{|l|}{ (7) Concern for job prospects } \\
\hline $\begin{array}{l}\text { I spend most of my time trying to get } \\
\text { to the top of the corporate ladder }\end{array}$ & $\begin{array}{l}16,5 \\
(40)\end{array}$ & $\begin{array}{l}28,0 \\
(68)\end{array}$ & $\begin{array}{l}33,7 \\
(82)\end{array}$ & $\begin{array}{l}21,8 \\
(53)\end{array}$ & 2.61 \\
\hline \multicolumn{6}{|l|}{ (8) Nature as sacred } \\
\hline $\begin{array}{l}\text { The earth can always provide for us } \\
\text { no matter how much we use its } \\
\text { resources *(CC negative response) }\end{array}$ & $\begin{array}{l}38,1 \\
(94)\end{array}$ & $\begin{array}{l}26,3 \\
(65)\end{array}$ & $\begin{array}{l}21,1 \\
(52)\end{array}$ & $\begin{array}{l}14,6 \\
(36)\end{array}$ & 2.12 \\
\hline $\begin{array}{l}\text { I feel ashamed that we have caused so } \\
\text { much damage to the planet }\end{array}$ & $\begin{array}{r}6,9 \\
(17)\end{array}$ & $\begin{array}{l}17,8 \\
(44)\end{array}$ & $\begin{array}{l}37,7 \\
(93)\end{array}$ & $\begin{array}{l}37,7 \\
(93)\end{array}$ & 3.06 \\
\hline \multicolumn{6}{|l|}{ (9) Concern over global warming } \\
\hline $\begin{array}{l}\text { "Global warming" is a hoax *(CC } \\
\text { negative response) }\end{array}$ & $\begin{array}{l}47,7 \\
(115)\end{array}$ & $\begin{array}{l}19,5 \\
(47)\end{array}$ & $\begin{array}{l}17,8 \\
(43)\end{array}$ & $\begin{array}{l}14,9 \\
(36)\end{array}$ & 2.00 \\
\hline $\begin{array}{l}\text { I use public transport often to reduce } \\
\text { my carbon emissions }\end{array}$ & $\begin{array}{l}13,6 \\
(33)\end{array}$ & $\begin{array}{l}28,8 \\
(70)\end{array}$ & $\begin{array}{l}37,9 \\
(92)\end{array}$ & $\begin{array}{l}19,8 \\
(48)\end{array}$ & 2.64 \\
\hline \multicolumn{6}{|l|}{ (10) Pro-feminism } \\
\hline I believe women are equal to men & $\begin{array}{c}6,6 \\
(16)\end{array}$ & $\begin{array}{l}11,9 \\
(29)\end{array}$ & $\begin{array}{l}23,8 \\
(58)\end{array}$ & $\begin{array}{l}57,8 \\
(141)\end{array}$ & $3 \cdot 33$ \\
\hline $\begin{array}{l}\text { Women are too caring and so should } \\
\text { NOT be managers/leaders *(CC } \\
\text { negative response) }\end{array}$ & $\begin{array}{l}58,0 \\
(142)\end{array}$ & $\begin{array}{l}22,9 \\
(56)\end{array}$ & $\begin{array}{l}12,2 \\
(30)\end{array}$ & $\begin{array}{l}6,9 \\
(17)\end{array}$ & 1.68 \\
\hline
\end{tabular}


The Revealing Case of Cultural Creatives as Transmodern Tourists in Soweto, South Africa

\begin{tabular}{|c|c|c|c|c|c|}
\hline \multicolumn{6}{|l|}{ (11) Altruism } \\
\hline $\begin{array}{l}\text { I gladly give my time, money and } \\
\text { skills to the underprivileged }\end{array}$ & $\begin{array}{r}5,9 \\
(14) \\
\end{array}$ & $\begin{array}{l}24,1 \\
(57)\end{array}$ & $\begin{array}{l}46,4 \\
(110)\end{array}$ & $\begin{array}{l}23,6 \\
(56)\end{array}$ & 2.88 \\
\hline $\begin{array}{l}\text { I actively participate in welfare } \\
\text { initiatives for homeless people }\end{array}$ & $\begin{array}{c}7,9 \\
(19)\end{array}$ & $\begin{array}{l}40,1 \\
(97)\end{array}$ & $\begin{array}{l}35,5 \\
(86)\end{array}$ & $\begin{array}{l}16,5 \\
(40)\end{array}$ & 2.61 \\
\hline $\begin{array}{l}\text { People should focus on helping } \\
\text { themselves, not others } \\
\text { *(CC negative response) }\end{array}$ & $\begin{array}{l}33,2 \\
(81)\end{array}$ & $\begin{array}{l}41,8 \\
(102)\end{array}$ & $\begin{array}{l}16,4 \\
(40)\end{array}$ & $\begin{array}{l}8,6 \\
(21)\end{array}$ & 2.00 \\
\hline \multicolumn{6}{|l|}{ (12) Reject neo-liberal economics } \\
\hline $\begin{array}{l}\text { I rely on marketing messages to help } \\
\text { me choose what I buy }\end{array}$ & $\begin{array}{l}21,4 \\
(54) \\
\end{array}$ & $\begin{array}{l}29,0 \\
(73) \\
\end{array}$ & $\begin{array}{l}31,3 \\
(79) \\
\end{array}$ & $\begin{array}{l}18,3 \\
(46) \\
\end{array}$ & 2.46 \\
\hline \multicolumn{6}{|l|}{ (13) Financial materialism } \\
\hline $\begin{array}{l}\text { Money is the ultimate measure of } \\
\text { progress in my life }\end{array}$ & $\begin{array}{l}16,7 \\
(42)\end{array}$ & $\begin{array}{l}40,9 \\
(103)\end{array}$ & $\begin{array}{l}23,4 \\
(59)\end{array}$ & $\begin{array}{l}19,0 \\
(48)\end{array}$ & 2.45 \\
\hline \multicolumn{6}{|l|}{ (14) Idealistic social contribution } \\
\hline $\begin{array}{l}\text { Volunteering in a local community is a } \\
\text { waste of time *(CC negative response) }\end{array}$ & $\begin{array}{l}50,4 \\
(125) \\
\end{array}$ & $\begin{array}{l}28,6 \\
(71)\end{array}$ & $\begin{array}{l}15,7 \\
(39)\end{array}$ & $\begin{array}{l}5,2 \\
(13) \\
\end{array}$ & 1.76 \\
\hline Compassion is the key to saving the world & $\begin{array}{l}2,8 \\
(7)\end{array}$ & $\begin{array}{l}22,2 \\
(55)\end{array}$ & $\begin{array}{l}45,6 \\
(113)\end{array}$ & $\begin{array}{l}29,4 \\
(73)\end{array}$ & 3.02 \\
\hline \multicolumn{6}{|l|}{ (15) Mass media tolerance } \\
\hline $\begin{array}{l}\text { Television is my daily source of } \\
\text { entertainment }\end{array}$ & $\begin{array}{l}31,1 \\
(78)\end{array}$ & $\begin{array}{l}35,5 \\
(89)\end{array}$ & $\begin{array}{l}25,9 \\
(65)\end{array}$ & $\begin{array}{c}7,6 \\
(19)\end{array}$ & 2.10 \\
\hline \multicolumn{6}{|l|}{ (16) Social concern/activist } \\
\hline $\begin{array}{l}\text { I participate in initiatives against: } \\
\text { Domestic violence and gender inequality }\end{array}$ & $\begin{array}{c}9,3 \\
(23)\end{array}$ & $\begin{array}{l}29,4 \\
(73)\end{array}$ & $\begin{array}{c}41,9 \\
(104)\end{array}$ & $\begin{array}{l}19,4 \\
(48)\end{array}$ & 2.71 \\
\hline I am actively involved in politics & $\begin{array}{l}21,0 \\
(52)\end{array}$ & $\begin{array}{l}40,7 \\
(101)\end{array}$ & $\begin{array}{l}29,8 \\
(47)\end{array}$ & $\begin{array}{l}8,5 \\
(21) \\
\end{array}$ & 2.26 \\
\hline
\end{tabular}

$\mathrm{N}(237-252) *$ negative response reveals the Cultural Creatives value

\section{The Dunnett T3 multiple comparison test of group differences}

The Dunnett T3 indicates that there is a statistically significant difference at the $p$ $<0.05$ level in the Mean scores of the three groups: $F(17.645, p=0.01, \mathrm{~N}=252)$. The variance for backpackers $\left(S^{2}=11.107\right)$, general tourists $\left(S^{2}=8.449\right)$ and for wandering tourists $\left(S^{2}=\right.$ 14.461) suggests that the groups are significantly dispersed from each other as they were targeted differently based on different tourist settings (backpacker - hostels, general tourists - coach tours and wandering tourists - unbeaten paths). The Mean score for general tourists $(M=16.60, S D=2.90, \mathrm{n}=50)$ is significantly different from wandering tourists $(M=$ 19.32, $S D=3.80, \mathrm{n}=151)$. Another significant Mean difference is between backpackers $(M$ $=20.67, S D=3.33, \mathrm{n}=51$ ) and general tourists. However, there is no statistical difference in the Mean score between backpackers and wandering tourists suggesting that wandering tourists and backpacker tourists uphold similar transmodern values.

\section{Results of Pearson's Chi-Square ( $\left.\mathrm{X}^{2}\right)$ and Crammer's Value (V)}

The Pearson's Chi-Square test is used to assess if there is a relationship between upholding a transmodern value system and the level of authenticity experienced while engaging in different activities and experiences in Soweto. The results of Pearson's ChiSquare $\mathrm{X}^{2}(2, \mathrm{n}=128)=9.462, \mathrm{p}=0.009$, where $\mathrm{p}<0.05$ reveals only one significant relationship between walking around a township and the level of authenticity experienced. The results of the Crammer's V measurement confirmed the results of Pearson's Chi. The cross classification for walking around a township $(\mathrm{n}=128)$ indicates an almost medium strength of relationship coinciding with Cohen's (1988) medium effect size ( 0.10 small, 0.30 medium and 0.50 large effect size) and is the highest Crammer's value $(V=0,272)$ of all the cross classifications. These tourists are the closest representatives of Cultural Creatives in a quest for immersive experiences, as predicted by the transmodern life values. 


\section{QUALITATIVE RESULTS}

The results of Thematic Content Analysis from 20 interviews are triangulated with the results of statistical tests and photographs to confirm the validity of statistically identified transmodern values and transformatory tourist experience.

\section{Theme 1: Transmodern values}

From the results presented in Table 2 it becomes evident that the majority of tourists visiting Soweto are actively concerned with social issues most evidently giving up their time, money or skills to the underprivileged (70\%), volunteering (79\%), and participating in initiatives against domestic violence and gender inequality (61.3\%).

"I was 18 (age) first time I was in Tanzania. I was volunteering with no values, but this really changed me... to be more open minded" (Austria, 2O-29, Female)

Tourists visiting poor localities such as townships are often criticised for disrespecting locals making them feel as if they are in a zoo by observing and photographing the locals from a moving tour bus (Ramchander, 2007). As the closest representatives of the Cultural Creatives, the tourists in the study exhibit a strong sense of restraint by not seeing themselves as merely spectators, but as human beings entering the living space of other human beings. Because Cultural Creatives are mindful of their impacts on local cultures, they are the most desired type of tourists to visit poor South African townships.

"Well I told them I don't really want to take pictures because people are living here and it's not like I went to the zoo or anything" (Germany, 20-19, Female)

Table 3. The Pearson's Chi-Square Test: The tourist activities related to authenticity of experience

\begin{tabular}{|l|c|c|c|c|c|}
\hline & $\begin{array}{c}\text { Pearson Chi- } \\
\text { Square (X) }\end{array}$ & $\begin{array}{c}\text { Asymptotic } \\
\text { Significance } \\
\text { (2-sided) }\end{array}$ & $\begin{array}{c}\text { Crammer's } \\
\text { Value (V) }\end{array}$ & df & $\begin{array}{c}\text { N of } \\
\text { Valid } \\
\text { Cases }\end{array}$ \\
\hline Mandela House Museum & 5.180 & 0.075 & 0.175 & 2 & 170 \\
\hline Orlando Towers Bungee & 1.490 & 0.475 & 0.147 & 2 & 69 \\
\hline Eating in local restaurants & 0.115 & 0,944 & 0.031 & 2 & 119 \\
\hline Hector Pieterson Museum & 0.836 & 0,658 & 0.080 & 2 & 131 \\
\hline Vilakazi Street tour & 2.048 & 0,359 & 0.133 & 2 & 115 \\
\hline Cycle tour & 2.623 & 0,269 & 0.161 & 2 & 101 \\
\hline Volunteering & 2.762 & 0,251 & 0.220 & 2 & 57 \\
\hline Visiting a crafts market & 1.627 & 0,443 & 0.112 & 2 & 130 \\
\hline Walking around a township & $\mathbf{9 . 4 6 2}$ & $\mathbf{0 , 0 0 9}$ & $\mathbf{0 , 2 7 2}$ & 2 & 128 \\
\hline
\end{tabular}

\section{Theme 2: Transformatory tourist experience}

The results in Table 2 clearly confirm deeper, transformatory meaning of travel as 84.5\% of the tourists feel that travelling helps reconfirm their life values, while $70.3 \%$ feel that their trip to South Africa helped them rediscover themselves.

"I think that's the whole purpose of travelling, to reconfirm values" (Austria, 2O29, Female)

A need for a 'live like a local' immersive experience denotes a search for meaningful consumption and growth through learning and discovery (Ivanovic, 2014; Morrison et al, 2017). In the case of the Cultural Creatives, it is the search for tourism offerings that lead to transformatory experiences that validate a sense of being true to one's (authentic) self (Ivanovic \& Saayman, 2015: 33). The tourists in the study indeed value human interaction and so undoubtedly express the desire for a tourism experience that involves varying degrees of immersion with the lives of the local people.

"Not just staying in a fancy hotel, eat at a restaurant, just do shopping and leave Johannesburg. Real vacation or real life is to be with the family and to be in their daily life... It was a big honour for me that I came in to their daily life and shared their daily life..." (Sweden, 30-39, Female) 


\section{Theme 3: Desire for Authenticity}

A desire for authenticity emerged as a critical component of the Soweto tourism offerings (Pine \& Gilmore, 2012; Gilmore \& Pine, 2007).

“...the whole Vilakazi street is like the less authentic part” (USA, 2O-29, Male)

Inauthentic pseudo sites, objects and tourism offerings do not impress contemporary travellers (Nicolaides, 2014:1). Paradoxically, places that are specifically designed for tourists seem to be the very places that deprive tourists from having an authentic experience. Tourists visiting Soweto clearly recognise the tourist settings are essentially staged and so the authenticity of the experience is seen as staged. Almost half of the tourists visiting a township in South Africa want to go for something more (George \& Booysens, 2014):

"Living with local people in their house" (France, 30-39, Male)

To help meet the authenticity requirement, tourist need to become active participants in the shaping of their own experiences. The triangulation of the results of Pearson's Chi-Square $\left(\mathrm{X}^{2=} 9.462, \mathrm{p}\right)$ and Crammer's Value (V) with the interview responses regarding the most authentic experience in Soweto, clearly confirm the statistical results that 'walking around the township' is the most authentic activity of Cultural Creatives.

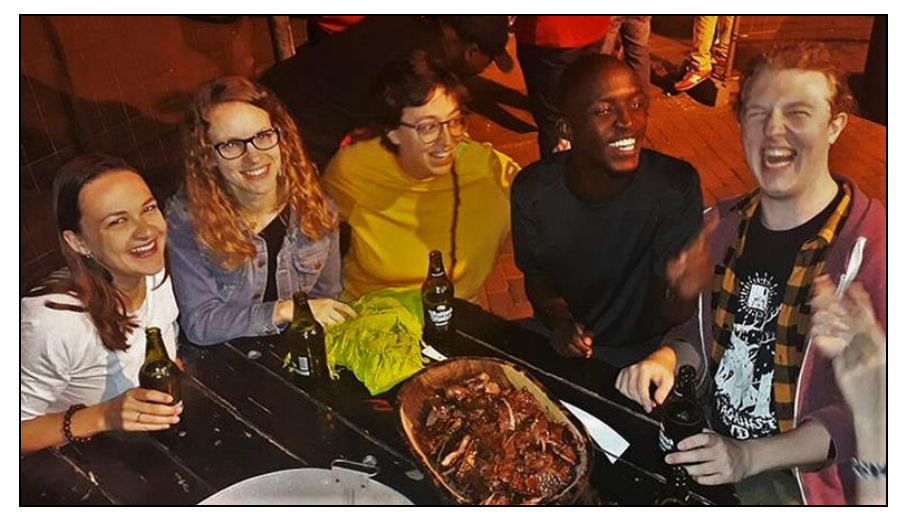

Figure 2. Students from Vienna enjoying a night out with one of the authors

(Soweto local) at the Bafokeng Corner Pub \& Grill, Phiri - South Soweto, 23 February 2018

"When we walked through the township" (Lithuania, 30-39, Female)

"No, I don't like that (tours), I like to walk" (Yemen, 20-29, Male)

"And there was also a small authentic moment for me when I just walked next to her down the street and it was actually a part of Soweto that she lives in" (Austria, 20-29, Female)

Ultimately, how tourists who uphold transmodern values (Cultural Creatives) interpret an authentic experience in Soweto is dependent on their ability to procure an intimate encounter with the locals through walking or other intimate interactions.

\section{CONCLUSION}

As the tourism industry matures, there is an increasing demand for unique, authentic and meaningful travel experiences (Morrison et al, 2017). The newly emerged consumers' sensibility towards authenticity is directly consequential of the current shift in the world consciousness towards self-actualization and authentic-self seen as the fundamental value of transmodernism tourism (Ivanovic \& Saayman, 2015:28). Based on the responses of the tourists on the worldview scale and the statistical results, it can be inferred that $54.8 \%(n=138)$ of the sample of tourists visiting Soweto can be considered as 
close representatives of a Cultural Creatives, while $45.2 \%(n=114)$ are general tourists. The findings of this study clearly show that in the South African tourist market, there are two times more (54.8\%) Cultural Creatives in Soweto than (26.1\%) expected by Ray (2008) in general population and almost three times more (18.3\%) than suggested by Ivanovic \& Saayman (2015). The second important finding of this study, based on the results of Pearsons-Chi, $\mathrm{X}^{2}(2, \mathrm{n}=128)=9.462$; and Crammer $\mathrm{V}, \mathrm{p}=0,009(V=0.272)$, is that the most authentic experience of Cultural Creatives in Soweto is walking around the township. Thirdly, the fact that xenophilism (89.6\%), self-actualisation (85.9\%) and desire to reconfirm life values $(84,5 \%)$, emerged as the most agreed values from the world-value scale, serves as a proof that transmodernism is not just some new construct invented by academics but a real value system adopted and endorsed by more than half of tourists visiting Soweto. It also confirms that Cultural Creatives are, in fact, 'conscious' travellers - the "new tourists in search for deep transformatory experiences pertinent to new (authentic) transmodern tourism" (Ivanovic, 2014:514). An emphasis on immersive, authentic tourism practices and the potential to encourage the use of local heritage and knowledge in order to meet the new transmodern demand for authentic, is the major finding of this study. However, any development of this nature in South African townships should be approached sensitively, as an act of open dialogue with the locals, and aligned with the values of transmodern tourism (Booysens, 2010; Strydom et al, 2019).

The main recommendation of this study is to focus on the development of transformative tourism offerings such are walking tours allowing tourists to interact with the local community in Soweto by visiting local businesses, various recreational centres and local homes for dining experiences. Therefore, locals should be encouraged to explore becoming hosts (e.g. AirBnB) or rent out accessories (e.g. bicycles, camping gear) and various expertise to travellers to facilitate more meaningful experiences for both travellers and locals. This is not only applicable for Soweto but other historically and culturally significant townships in South Africa and Africa.

Lastly, due to the vast heterogeneity within the groups of Cultural Creatives it is recommended that the future studies related to the transmodern tourism should complement motivations with tourist life values for understanding tourist behaviour and social transformation in various destinations in Africa and South Africa.

\section{REFERENCES}

AfriGis. (2019). Map of Soweto. Available from: https://maps.google.com $/ \mathrm{maps} / \mathrm{ms}$ ?msa=0\&msid=20378 99731. (Accessed: 14 June 2019).

Ateljevic, I. (2009). Transmodernity: Remaking our (Tourism) World? In Tribe, J. Philosophical Issues in Tourism. Bristol: Channel View Publications. pp. 278-300.

Ateljevic, I. (2011). Transmodern Critical Tourism Studies: A Call for Hope and Transformation. Turismo Em Análise, 22(3):497-515. https://doi.org/10.1.1.833.5801.

Ateljevic, I. (2013). Transmodernity: Integrating perspective on Societal Evolution. Futures, 47:38-48. http://dx.doi.org/10.1016/j.futures.2013.01.002

Booysens, I. (2010). Rethinking Township Tourism: Towards Responsible Tourism Development in South African Townships. Development Southerm Africa, 27(2):273-287. https://doi.org/10.108o/o37683510037 40795.

Carvache-Franco, M., Segarra-Oña, M., \& Carrascosa-López, C. (2019). Motivations Analysis in Ecotourism through an Empirical Application: Segmentation, Characteristics and Motivations of the Consumer. Geojournal of Tourism and Geosites, 24(1):60-73. https://doi.org/10.30892/gtg.24106-343.

Dussel, E. (2002). World-system and 'Trans'-modernity. Nepanthia: Views From the South, 3(2): 221-244.

Florida, R. L. (2012). The Rise of the Creative Class, Revisited. New York: Basic Books.

George, R. \& Booysens, I. (2014). Township Tourism Demand: Tourists' Perceptions of Safety and

Gelter, H. (2010). Total Experience Management - A Conceptual Model for Transformational Experiences within Tourism. Conference Proceedings of the Nordic Conference on Experience 2008. Research, Education and Practice in Media: Medusa Group of Vaasa Consortium of Higher Education. Finland: Vaasa, pp. 46-78.

Ghisi, M. L. (1999). The Transmodern Hypothesis: Toward a Dialogue of Cultures. Futures, 31(9-10):879-1016. 
Ghisi, M. L. (2008). The Knowledge Society: A Breakthrough towards Genuine Sustainability. Cochin, India: Arunachala Press.

Ghisi, M.L. (2010). Towards a Transmodern Transformation of our Global Society: European Challenges and Opportunities. Journal of Future Studies, 15(1):39-48. https://doi.org/10.1016/soo16-3287 (99)ooo56-7).

Gilmore, J.H. \& Pine, J.B. (2007). Authenticity: What Consumers Really Want? Boston: Harvard Business School Press.

Ivanovic, M. (2014). The Perceived Authenticity of Iconic Heritage Sites in Urban Tourism: The Case of Constitution Hill, Johannesburg, South Africa. Urban Forum, 25:501-515. Ivanovic, M. \& Saayman, M. (2015). Authentic Economy Shaping Transmodern Tourism Experience. African Journal for Physical, Health Education, Recreation and Dance, Supplement 1 (December), pp. $24-36$.

Jeong, Y., Zielinski, S., Chang, J. S., \& Kim, S. I. (2018). Comparing Motivation-Based and Motivation-AttitudeBased Segmentation of Tourists Visiting Sensitive Destinations. Sustainability, 10:3615(1-16). https://doi.org/10.30892/gtg.24105-342.

Meconnen, B. (2012). Reinventing the World? Trans-modernity's Emancipatory and Communicative Possibilities. Ethiopian Journal of the Social Sciences and Humanities, 8(1):1-30.

Morrison, A.M. Paulauskaite, D. Powell, R. \& Coca-Stefaniak, J.A. (2017). Living like a Local: Authentic Tourism Experiences and the Sharing Economy. International Journal of Tourism Research, 19:619-628. https://doi.org/10.1002/jtr.2134.

Nicolaides, A. (2014). Authenticity and the Tourist's Search for Being. African Journal of Hospitality, Tourism and Leisure, 3(1):1-11.

Pallant, J. (2011). SPSS Survival Manual: A Step by Step Guide to Data Analysis Using the SPSS Program. (4th Ed). Berkshire: Allen \& Unwin.

Pine J.B. \& Gilmore, J.H. (2012). The Experience Economy: Work is Theatre \& Every Business a Stage. Boston: Harvard Business School Press.

Pritchard, A. Morgan, N. \& Ateljevic, I. (2011). Hopeful Tourism: A New Transformative Perspective. Annals of Tourism Research, 38:941-963. https://doi.org/10.1016/j.annals.2011.01.004.

Rahi, S. (2017). Research Design and Methods: A Systematic Review of Research Paradigms, Sampling Issues and Instruments Development. International Journal of Economics \& Management Science, 6(2):1-5. DOI: $10.4172 / 2162-6359.1000403$.

Ramchander, P. (2007). Township Tourism: Blessing or Blight? The Case of Soweto in South Africa. In G. Richards (Ed.), Cultural Tourism: Global and Local Perspectives New York: Haworth Press, pp.39-67.

Ray, H. P. (2008). The Potential for a New, Emerging Culture in the U.S. Report on the 2008 American Values Survey. 19p. Available from: https://www.wisdomuniversity.org/CCsReport2008SurveyV3.pdf. (Accessed: 21 May 2019).

Ray, H. P. \& Anderson, S. R. (2000). The Cultural Creatives: How 50 Million People Are Changing the World? New York: Harmony Books.

Reisinger, Y. (2015). Preface. In Y. Reisinger (Ed.). Transformational Tourism: Host Perspectives. pp. Xii-Xiii. Wallingford: CABI.

Richards, G. (2011). Globalisation, Localisation and Cultural Tourism. Tram-Research. Available From: www. aumed.net/richards.pdf. (Accessed: 21 May 2019).

Rifkin, J. (2005). The European Dream: How Europe's Vision of the Future is Quietly Eclipsing the American Dream. New York: Penguin Group.

Robledo, M. A., \& Batle, J. (2017). Transformational Tourism as a Hero's Journey. Current Issues in Tourism, 20(16):1736-1748. https://doi.org/10.1080/13683500.2015.1054270.

Rodríguez, M. R. (1989). La Sonrisa De Saturno: Haciauna Teoría Transmoderna. Barcelona: Anthropos.

Rodríguez, M. R. (2017). Transmodernity: A New Paradigm (translated). Available From: http://trans moderntheory.blogspot.com.es/2017/05/transmodernity-new-paradigm.html/. (Accessed: 21 May 2019).

SAT, South African Tourism. (2017). 2016 Annual Tourism Report. Johannesburg: SAT.

Stats SA. (2018). Tourism and Migration. Statistics Release, January. Pretoria. StatsSA. Available From: http://www.statssa.gov.za/publications/po351/p0351january2018.pdf. (Accessed: 21 May 2019).

Strydom, A.J., Mangope, D., \& Henama, U.S. (2019). Making Community-Based Tourism Sustainable: Evidence from the Free State Province, South Africa. Geojournal of Tourism and Geosites, 24(1), 7-18.

Tomljenovic, R. (2015). Transformative Tourism: Theoretical and Methodological Review. Available From: https://www.researchgate.net/publication/299489264. (Accessed: 21 May 2019).

Welzel, C. (2006). A Human Development View on Value Change Trends (1981-2006), International University Bremen (IUB). Istanbul Presentation Held Professor of Political Science, November 03, 2006. Available From: www.worldvaluessurvey.org (Accessed: 21 May 2019).

Wolf, I. D. Ainsworth, G. B. \& Crowley, J. (2017). Transformative Travel as a Sustainable Market Niche for Protected Areas: A New Development, Marketing and Conservation Model. Journal of Sustainable Tourism, 25(11):1650-1673. https://doi.org/10.1080/09669582.2017.1302454.

Submitted:

11.07.2019
Revised:

16.10 .2019
Accepted and published online 18.10.2019 